\title{
Analysis of China's Natural Gas Use Policies and Suggested Reforms
}

\subsection{Development of China's Natural Gas Use Policy}

\subsubsection{The Encouraging Consumption Stage}

Before the Shaan-Jing natural gas pipeline began operation in 1997, China's only gas pipeline to reach a length of over $350 \mathrm{~km}$ was the Hong Kong offshore gas pipeline (Yacheng-Hong Kong, $778 \mathrm{~km}$ ). Owing to the lack of cross-regional gas pipelines, natural gas in China was characterised by being produced in nearby fields. At that time, the two most important markets for natural gas were Sichuan and the North East. The Sichuan Basin has a long history of developing natural gas and already has a highly developed network of pipelines. The North East gas fields can produce high-quality oil-associated gas. The main uses of natural gas are primarily in the chemical industry, where it is used to produce methanol and fertilisers. Much associated gas is vented or consumed by oil companies during production. Urban gas and industrial fuel usage is limited to areas adjacent

\footnotetext{
* This chapter was overseen by Zhaoyuan Xu from the Development Research Center of the State Council and Martin Haigh from Shell International, with contributions from Baosheng Zhang and Shouhai Chen from the China University of Petroleum, Lianzeng Zhao from the China Petroleum Planning Research Institute, Linji Qiao from ENN and Juan Han from Shell China. Other members of the research group participated in discussions and revisions.
}

to sources, and only constitutes a fraction of total natural gas consumption (see Table 6.1).

China's natural gas exploration in the 1990s was extremely fruitful. In total, nine large gas fields and 32 medium-sized gas fields were discovered. Taken together, these make up the six major gas regions of Sichuan, Ordos, Tarim, Qaidam, the East China Sea and the Ying-Qiong area, of which the Jingbian gas field is the largest, with proven reserves of 290.09 billion $\mathrm{m}^{3}$. The discovery of large natural gas reserves stimulates the construction of long-distance gas pipelines. These include the Shaanxi gas entry to Beijing, western gas being piped east, Sichuan gas being piped east and offshore gas terminals. In 2003 the IEA noted that the development of China's natural gas market had many obstacles to overcome, the first being increasing demand for natural gas. At that time, the main problems facing the natural gas industry were competing with cheap coal and creating demand for, rather than restricting use of, natural gas.

\subsubsection{Restricted Usage Stage}

With the completion of the western gas piped east project, a new era in the development of China's natural gas markets commenced. The markets changed from being regional to being national, freeing up supply and leading to a sharp increase in production. This brought about a shift in market trends. There had previously been worries that there were not enough consumers of natural gas, but suddenly there was not enough supply to meet the demand. In 2005, the National 
Table 6.1 China's natural gas consumption structure in 1998 (excluding Hong Kong)

\begin{tabular}{|l|l|l|l|l|l|l|}
\hline Item & $\begin{array}{l}\text { Gas used in the chemicals } \\
\text { industry }\end{array}$ & $\begin{array}{l}\text { Industrial } \\
\text { fuels }\end{array}$ & $\begin{array}{l}\text { Urban } \\
\text { gas }\end{array}$ & $\begin{array}{l}\text { Oil } \\
\text { production }\end{array}$ & Miscellaneous & Total \\
\hline $\begin{array}{l}\text { Consumption } \\
\left(\times 10^{8} \mathrm{~m}^{3}\right)\end{array}$ & 89.64 & 18.53 & 24.12 & 56.68 & 13.6 & 202.57 \\
\hline \begin{tabular}{l} 
Percentage \\
\hline
\end{tabular} & 44.25 & 9.1 & 11.9 & 28 & 6.7 & 100 \\
\hline
\end{tabular}

Data source National Bureau of Statistics

Table 6.2 Natural gas prices in 2005 after price adjustments $\left(\mathrm{CNY} / 1000 \mathrm{~m}^{3}\right)$

\begin{tabular}{|c|c|c|c|c|c|c|}
\hline & & $\begin{array}{l}\text { Sichuan-Chongqing } \\
\text { gas fields }\end{array}$ & $\begin{array}{l}\text { Changqing gas } \\
\text { fields }\end{array}$ & $\begin{array}{l}\text { Qinghai oil } \\
\text { fields }\end{array}$ & $\begin{array}{l}\text { Xinjiang oil } \\
\text { fields }\end{array}$ & $\begin{array}{l}\text { Other oil } \\
\text { fields }\end{array}$ \\
\hline \multirow[t]{3}{*}{$\begin{array}{l}\text { First-grade } \\
\text { gas }\end{array}$} & $\begin{array}{l}\text { Gas for } \\
\text { fertiliser }\end{array}$ & 690 & 710 & 660 & 560 & 660 \\
\hline & $\begin{array}{l}\text { Industrial } \\
\text { gas }\end{array}$ & 875 & 725 & 660 & 585 & 920 \\
\hline & Urban gas & 920 & 770 & 660 & 560 & 830 \\
\hline $\begin{array}{l}\text { Second-grade } \\
\text { gas }\end{array}$ & 980 & & & & & \\
\hline
\end{tabular}

Development and Reform Commission tried to adjust prices in order to regulate the use of natural gas. This led to the decision to revise the manufacturer's natural gas pricing mechanism, raising the manufacturer's natural gas price by an appropriate amount, encouraging gas use efficiency, optimising gas use structures and promoting healthy and sustainable development of industrial gas use, all in order to ensure supplies to the Chinese natural gas market. It was made known that all oilfield gas not subject to planning would be treated as second-grade gas and would be priced based on the government guidelines at $980 \mathrm{CNY} / 1000 \mathrm{~m}^{3}$. Price increases would be limited to $10 \%$, but there would be no bottom limit. The price of first-grade gas was raised by an appropriate amount, the government being responsible for price regulation, with upper and lower limits of $10 \%$ (see Table 6.2).

The 2005 natural gas price adjustment still failed to effectively curb the rapid growth in demand for natural gas. This was largely due to the price of gas being relatively low, concentrated development of the gas-based chemicals industry in areas adjacent to gas production sources and a mad rush to develop low added value, short industrial chain methanol and fertiliser plants in various areas. In August 2007, in order to resolve the conflicts arising in supply and demand, the National Development and Reform Commission issued a new natural gas use policy. The Commission divided natural gas use into four distinct categories (priority, permitted, restricted and prohibited) and took an interventionist policy toward its use. Such measures prioritised eco-friendly urban gas uses (see Table 6.3).

\subsubsection{Flexible Restrictions Stage}

The Chinese government has implemented many policies to meet the growing domestic demand for natural gas. First, it aimed to limit large-scale natural gas and chemical projects. Second, it raised gas prices to encourage natural gas production and imports. Between 2002 and 2012, China's natural gas production more than doubled, from 32.7 to 107.2 billion $\mathrm{m}^{3}$. During this time, China was also actively importing overseas resources. On May 25, 2006 the first shipment of LNG entered Dapeng Bay in Shenzhen from Australia's North West Shelf. This marked the beginning of a new era for China's imports of natural gas. In 2010, the Central Asian gas 
Table 6.32007 natural gas usage policy

\begin{tabular}{|c|c|c|}
\hline $\begin{array}{l}\text { Order of } \\
\text { priority }\end{array}$ & Field of use & \\
\hline $\begin{array}{l}\text { Highest } \\
\text { priority }\end{array}$ & Urban gas & $\begin{array}{l}\text { 1. Cities (especially medium-large cities), residential cooking, boiling water and } \\
\text { other residential uses } \\
\text { 2. Public service facilities (airports, government offices, canteens, nursery } \\
\text { schools, schools, hotels, restaurants, shopping centres, office buildings, etc.) } \\
\text { 3. Natural gas vehicles (especially dual-fuel vehicles) } \\
\text { 4. Distributed co-generation and CCHP users }\end{array}$ \\
\hline \multirow[t]{4}{*}{ Permitted } & Urban gas & $\begin{array}{l}\text { 1. Centralised heating (in city centres) } \\
\text { 2. Individual household heating } \\
\text { 3. Central air conditioning }\end{array}$ \\
\hline & Industrial gas & $\begin{array}{l}\text { 4. Industrial fields in which natural gas may replace oil or LPG, such as for } \\
\text { building materials, machinery, textiles, petrochemicals and metallurgy } \\
\text { 5. Industrial fields in which natural gas is a more sustainable substitute than coal } \\
\text { gas, or is economically beneficial. Examples include building materials, } \\
\text { machinery, textiles, petrochemicals and metallurgy and other industrial fields } \\
\text { where adoption of natural gas offers relatively high environmental and } \\
\text { economic benefits } \\
\text { 6. Building materials, machinery, textiles, petrochemicals, metallurgy }\end{array}$ \\
\hline & $\begin{array}{l}\text { Natural gas power } \\
\text { generation }\end{array}$ & $\begin{array}{l}\text { 7. Construction of natural gas peak regulation infrastructure for main power } \\
\text { loading centre(s) in regions with sufficient natural gas supplies }\end{array}$ \\
\hline & $\begin{array}{l}\text { Gas chemical } \\
\text { industry }\end{array}$ & $\begin{array}{l}\text { 8. Economically beneficial hydrogen gas projects that consume gas on a small } \\
\text { scale } \\
\text { 9. Ammonia and fertiliser producers that would be incapable of moving or } \\
\text { category } 1 \text { and } 2 \text { users to which the regulations do not apply }\end{array}$ \\
\hline \multirow[t]{2}{*}{ Restricted } & $\begin{array}{l}\text { Natural gas power } \\
\text { generation }\end{array}$ & $\begin{array}{l}\text { 1. Construction of natural gas power stations in non-crucial power loading } \\
\text { centres }\end{array}$ \\
\hline & $\begin{array}{l}\text { Gas chemical } \\
\text { industry }\end{array}$ & $\begin{array}{l}\text { 2. Extension of pre-existing synthetic ammonia facilities relying on natural gas, } \\
\text { conversion of synthetic ammonia facilities from coal to natural gas } \\
\text { 3. Carbon } 1 \text { chemical engineering projects with primary methane-based } \\
\text { products, including acetylene and chloromethane } \\
\text { 4. New synthetic ammonia projects relying on natural gas, other than those } \\
\text { included in item } 9 \text { of category } 2\end{array}$ \\
\hline \multirow[t]{2}{*}{ Prohibited } & $\begin{array}{l}\text { Natural gas power } \\
\text { generation }\end{array}$ & $\begin{array}{l}\text { 1. Construction of base-load natural gas power stations in } 13 \text { large-scale coal } \\
\text { mining regions including Shaanxi, Mongolia, Shanxi and Anhui }\end{array}$ \\
\hline & $\begin{array}{l}\text { Gas chemical } \\
\text { industry }\end{array}$ & $\begin{array}{l}\text { 1. New construction or extension of methanol production facilities relying on } \\
\text { natural gas } \\
\text { 2. Projects for the replacement of coal with natural gas for the production of } \\
\text { methanol }\end{array}$ \\
\hline
\end{tabular}

pipeline began delivering gas to China and in 2013 the China-Burma pipeline was brought online. Based on the Natural Gas Development Plan, China's annual imports of natural gas will reach 93.5 billion $\mathrm{m}^{3}$ by 2015 , which will account for one third of the entire gas supply. This increase in the supply of offshore gas resources, in conjunction with the rapid increase and growth of domestic natural gas production, means that the hitherto problematic situation of China's gas supply has been greatly eased.
In October 2012, the National Development and Reform Commission adapted its policy on natural gas use (see Table 6.4) and relaxed restrictions on a number of specific gas use fields:

- In terms of policy objectives, there was no longer an emphasis on relieving conflicts between supply and demand. Encouragement of a low-carbon economy was added, as was 
Table 6.42012 natural gas usage policy

\begin{tabular}{|c|c|c|}
\hline Order of & \multicolumn{2}{|l|}{ Field of use } \\
\hline \multirow[t]{3}{*}{$\begin{array}{l}\text { Highest } \\
\text { priority }\end{array}$} & Urban gas & $\begin{array}{l}\text { 1. Urban areas (especially medium-large cities), residential cooking, boiling } \\
\text { water and other residential usages } \\
\text { 2. Gas used for public service facilities (airports, government offices, canteens, } \\
\text { nursery schools, hospitals, hotels, bars, restaurants, department stores, office } \\
\text { buildings, stations, welfare offices, old people's homes, harbours, pier } \\
\text { terminals and bus stations) } \\
\text { 3. Natural gas vehicles (especially dual-fuel and liquefied natural gas vehicles), } \\
\text { including city buses, taxis, commercial vehicles, passenger vehicles, } \\
\text { sanitation lorries and other transport vehicles that rely on natural gas as fuel } \\
\text { 4. Centralised heating (in city centres) } \\
\text { 5. Gas air conditioning }\end{array}$ \\
\hline & Industrial gas & $\begin{array}{l}\text { 6. Building materials, machinery, textiles, petrochemicals, metallurgy } \\
\text { 7. Interruptible hydrogen manufacturing projects relying on natural gas }\end{array}$ \\
\hline & Other users & $\begin{array}{l}\text { 8. Natural gas distributed energy projects (comprehensive energy efficiency } \\
\text { above } 70 \% \text {, including the use of renewable energy sources) } \\
\text { 9. As fuel in sea-going, river-going and lake-going vessels (including } \\
\text { gas-fuelled and dual-fuelled vessels) that rely on natural gas (especially LNG) } \\
\text { 10. Towns that have an emergency and peak regulation natural gas storage } \\
\text { facilities } \\
\text { 11. Coalbed methane (marsh gas) power generation projects } \\
\text { 12. Natural gas co-generation projects }\end{array}$ \\
\hline
\end{tabular}

Permitted Urban gas

Industrial gas

Natural gas power generation

Gas chemical industry

Restricted Gas chemical industry

Prohibited Natural gas power generation

Gas chemical industry

\section{Individual household heating users}

2. Projects in which natural gas is used as a replacement for oil or LPG, such as building materials, machinery, textiles, petrochemicals and metallurgy

3. New projects where natural gas is used as fuel, including building materials, machinery, textiles, petrochemicals and metallurgy

4. Projects where the adoption of natural gas as a replacement for coal offers environmental and economic benefits, including building materials, machinery, textiles, petrochemicals and metallurgy

5. Urban projects for conversion of industrial boilers to gas (especially in medium-large cities)

6. All natural gas power projects excluding item 12 in the first category and item 1 in the fourth category

7. Natural gas hydrogen production projects excluding item 7 in the first category

8. Small natural gas liquefaction facilities for peak regulation and storage

1. Extension of existing natural gas-based ammonia plants and conversion of ammonia plants from coal to natural gas

2. Carbon 1 chemical engineering projects with primary methane-based products, including acetylene and chloromethane

3. New urea fertiliser projects that use natural gas as raw material

1. Base-load power generator construction projects in 13 large-scale coal mining regions including Shaanxi, Mongolia, Shanxi and Anhui (excluding coal bed methane (marsh gas) power generation projects)

2. New construction or extension of natural gas-based methanol plants and downstream methanol production projects

3. Projects for methanol manufacturing using natural gas as replacement of coal 
increasing the proportion of primary energy sources accounted for by natural gas.

- Restrictions applicable to natural gas power were relaxed, but the prohibition on gas power construction projects (excluding coalbed methane (marsh gas) power generation projects) in 13 regions with large-scale coal bases continued, including Shaanxi, Inner Mongolia, Shanxi and Anhui. The categories of other natural gas-based power generation projects were changed from "permitted" or "prohibited" to "highest priority" and "permitted".

- There was relaxation of restrictions on use of natural gas as an industrial fuel, in centralised heating and by interruptible users in the fields of building materials, machinery and electronics, textiles, the petrochemicals industry, metallurgy and other industrial fields, who had their categories changed from being "permitted" to "highest priority".

\section{2 "Optimisation" of Natural Gas Use Structures and Policies}

China's policy on natural gas use clearly states that one of its main goals is to optimise the structure of natural gas use. So what exactly are "optimised" gas use structures, and how is their "optimisation" to be achieved?

Table 6.5 2003-2011 China natural gas use structure

\begin{tabular}{|c|c|c|c|c|c|c|c|c|c|}
\hline & 2003 & 2004 & 2005 & 2006 & 2007 & 2008 & 2009 & 2010 & 2011 \\
\hline Oil field internal use & 79.44 & 72.77 & 78.88 & 77.44 & 85.59 & 104.41 & 117.40 & 129.55 & 126.04 \\
\hline $\begin{array}{l}\text { Power generation and } \\
\text { heating }\end{array}$ & 7.54 & 12.74 & 18.78 & 29.49 & 70.74 & 73.92 & 127.91 & 180.80 & 215.90 \\
\hline Industrial fuels & 45.71 & 70.22 & 89.69 & 99.62 & 116.29 & 153.24 & 155.75 & 183.29 & 264.5 \\
\hline $\begin{array}{l}\text { Chemical engineering raw } \\
\text { materials }\end{array}$ & 128.13 & 122.90 & 141.44 & 177.42 & 207.05 & 200.03 & 176.84 & 187.28 & 233.48 \\
\hline Transport and logistics & 18.82 & 26.16 & 38.01 & 47.24 & 46.88 & 71.55 & 91.07 & 106.70 & 138.35 \\
\hline Commercial use gas & 6.85 & 9.18 & 10.79 & 13.16 & 17.11 & 17.75 & 23.96 & 27.24 & 33.64 \\
\hline Residential & & & 79.43 & 102.63 & 143.39 & 170.10 & 177.70 & 226.90 & 264.38 \\
\hline Other gas use & & 14.14 & 9.12 & 12.77 & 16.09 & 20.92 & 23.64 & 26.00 & 27.14 \\
\hline Total & 286.49 & 328.11 & 466.14 & 559.77 & 703.14 & 811.92 & 894.27 & 1067.76 & 1303.46 \\
\hline
\end{tabular}

\subsubsection{China's Natural Gas Use Structure}

The structure of natural gas usage refers to the proportion of natural gas used in different areas relative to overall consumption. Before 2000, due to a lack of inter-regional pipelines, oil field production self-usage and chemical engineering adjacent to oil fields accounted for the vast majority of China's natural gas consumption. Urban gas and gas used for generating power accounted for a very small proportion (see Table 6.5). Once long-distance pipelines were brought online, the gas-using regions spread from being concentrated around oil and gas fields towards the more economically advanced central and eastern regions (see Table 6.5). In 2013, out of a total consumption of 166 billion $\mathrm{m}^{3}$ of natural gas in China, urban gas (including gas used in vehicular and waterborne transport) and industrial fuel consumption together accounted for $67 \%$ of total consumption.

\subsubsection{Worldwide There Is no Such Thing as "Optimised" Gas Use Structure}

In 1998, the chemical industry accounted for $44.5 \%$ of Chinese natural gas consumption. By 2007 , this proportion had dropped to $30 \%$. In 2007, when natural gas use policy was introduced, the structure of China's natural gas use was far
Unit $10^{8} \mathrm{~m}^{3}$ 
from ideal, mainly reflected by the chemical industry accounting for a disproportionately large proportion of total natural gas consumption. In light of this, the natural gas chemicals industry should have been classified as a restricted or prohibited gas use field. In 2011, gas use in the chemical industry dropped to $18 \%$, then $15 \%$ in 2013. In 2012, when the National Development and Reform Commission issued the gas use policy, the main objectives were still optimising gas use structure and restricting and prohibiting use of natural gas in chemical engineering.

Global natural gas use structures can be divided into three types: a balanced structure type, a mainly power generation type and an urban gas use type. The United States is a typical balanced structure, with urban gas, power generation and industrial gas (including industrial fuels and gas for use in chemical engineering) each constituting roughly one third. Japan, South Korea and Russia use natural gas predominantly for power generation. Japan, for example, used 94.5 billion $\mathrm{m}^{3}$ of natural gas in 2010 , of which $60 \%$ was used to produce electricity. After the Fukushima nuclear accident in 2011, an even higher proportion of natural gas was used to generate electricity. Consumption of natural gas in The Netherlands and the United Kingdom, two Western European countries, is predominantly urban. In 2010, the Dutch consumed 43.6 billion $\mathrm{m}^{3}$ of gas, of which urban gas accounted for 56\%, industrial fuels for $33 \%$ and power generation usage for $11 \%$ (Canqi 2014: 1-2). Looking at the historical development of China's natural gas output in the light of the experiences of other countries, it is clear that there is no such thing as a standard optimised structure in terms of natural gas use.

Even though there is no standard optimised structure, it doesn't mean that standards don't exist for the optimisation of natural gas use. The National Development and Reform Commission in its policy on gas use proposed that the use of natural gas should be optimised according to three criteria: social benefit, environmental benefit and economic benefit, though it does not define what is meant by social, environmental and economic benefits. However, based on the order in which they apply to gas use, "social benefit" refers to living standards and the guarantee of residential gas supplies, in order to avoid social unrest due to gas shortages. This is why the domestic uses of cooking and boiling have been listed as prioritised areas of gas use. Environmental benefits include the reduction of emissions. This is the reason for the inclusion of gas-powered vehicles, centralised heating, industrial fuels, distributed energy resources and co-generation in the "permitted" and "top priority" categories. Finally, economic benefits concern profits derived from market sales, and therefore it is the overruling factor in deciding the prioritisation of natural gas use. The "optimisation" of natural gas use structures should therefore seek to maximise social, environmental and economic benefits.

\subsubsection{Market Pricing Adjustments Would Automatically Result in "Optimisation" of Natural Gas Use Structures}

In order to "optimise" natural gas use structures, the National Development and Reform Commission developed a specific gas use policy. This policy also classifies the use of gas as being either highest priority, permitted, restricted or prohibited, and thus established the order of priority. Chinese economist Hua Ben analysed the capacity and affordability of five markets in the lower reaches of the Yangtze in terms of power generation, urban gas, industrial and commercial fuels, transportation fuels and chemical raw materials. He then performed a feasibility study on natural gas, concluding that, given that natural gas costs 2.5 times more for the same calorific value when compared to coal and other fuels, a combined cycle power plant cannot compete with coal power generation in terms of basic load and can only be used for peak regulation. Urban use of gas fuel is less price-sensitive, but the volume used is limited. Industrial and commercial gas use is the largest end user market for natural gas. CCHP systems improve natural gas pricing tolerance and are 
currently key to the efficient use of natural gas in China. LNG has advantages as a vehicle gas fuel. Compared to coal, natural gas is not economically viable for use as a raw material in the chemical engineering industry. Based on Hua Ben's theoretical results, there is absolutely no need for the government to implement gas use policies, as price adjustments will automatically result in "optimisation" of gas use structures and natural gas is not economically viable for use in power generation or as a raw material in chemical engineering.

Regarding the problem of the use of natural gas in chemical engineering, however, it is likely that natural gas producers and local governments in gas-producing areas may have applied different methods of calculation. Where natural gas producers are concerned, due to the natural gas price being controlled by the government, revenues from external sales of natural gas are limited, while they are required to provide peak regulation and ensure supplies. However, development of industrial natural gas use near oil and gas fields is stable, since natural gas costs less when the price doesn't include a transport element. In addition, there is no regulation of the price of chemical products, allowing higher levels of income to be achieved. From the perspective of local governments in natural gas-producing regions, external sale of locally produced natural gas results in meagre earnings from resource tax (5\% of the selling price). Therefore, local development of a natural gas chemical industry will not only help increase local tax revenue and provide employment, but can also promote local economic development. When one does the math, this is an additional impetus for natural gas producers and governments in gas-producing regions to develop the natural gas chemicals industry.

A basic approach to "optimising" gas use structure involves natural gas tax reform and environmentally-friendly policy, accompanied by reorganisation of the natural gas pricing mechanisms, all which should work together so that natural gas projects that bring greater social and environmental benefits have access to greater economic benefits as a result. It is preferable to reduce the effects of government intervention in specific markets to a minimum. Experience of government interference in natural gas markets between the mid-1950s and the 1980s in the United States has already taught us the lesson that, whether pricing controls or usage controls are employed, neither are helpful in the development of a healthy natural gas industry.

\subsection{Natural Gas Use and Natural Gas Price Controls}

\subsubsection{Natural Gas Price Control Policies in China}

Due to the existence of a monopoly in the natural gas market, it has been difficult for market pricing mechanisms to emerge, and thus natural gas prices have always been controlled by the government in China. The prices at which upstream corporations sell natural gas are determined by the National Development and Reform Commission, and the prices at which the downstream corporations sell natural gas are determined by pricing departments within local government. Before the natural gas price reforms of June 2013, the National Development and Reform Commission set manufacturers' natural gas prices according to the price of alternative energy sources (limiting increases to $10 \%$, with no bottom limit), with gas being priced differently for different uses. In the natural gas price reforms of 2013, the National Development and Reform Commission decided to use alternative energy sources as a pricing reference, and, based on considerations of the main directional flow of natural gas market resources and pipeline costs, established gate prices by the netback market value method. The gate prices are set temporarily and adjusted annually, and no further distinction is made regarding different uses, while the goal is to merge stored gas and incremental gas prices within three years. In the second half of 2014 , international oil prices fell drastically, based on the price adjustment formula established in 2013, the National Development and Reform Commission then issued the Notice on Reorganising 
Table 6.6 Maximum natural gas gate prices by province (region, city) after 2015 price adjustments

\begin{tabular}{|l|l|l|l}
\hline Province & Maximum gate price & Province & Maximum gate price \\
\hline Beijing & 2700 & Hubei & 2660 \\
Tianjin & 2700 & Hunan & 2660 \\
\hline Hebei & 2680 & Guangdong & 2880 \\
Shanxi & 2610 & Guangxi & 2710 \\
\hline Inner Mongolia & 2040 & Hainan & 2340 \\
\hline Liaoning & 2680 & Chongqing & 2340 \\
\hline Jilin & 2460 & Sichuan & 2350 \\
\hline Heilongjiang & 2460 & Guizhou & 2410 \\
\hline Shanghai & 2880 & Yunnan & 2410 \\
\hline Jiangsu & 2860 & Shaanxi & 2040 \\
\hline Zhejiang & 2870 & Gansu & 2130 \\
\hline Anhui & 2790 & Ningxia & 2210 \\
\hline Jiangxi & 2660 & Qinghai & 1970 \\
\hline Shandong & 2680 & Tibet & 1850 \\
\hline Henan & 2710 & & \\
\hline Unit CNY/10 & (in & & \\
\hline
\end{tabular}

Unit $\mathrm{CNY} / 10^{3} \mathrm{~m}^{3}$ (including value added tax)

Data source Pricing variation order (2015)351: Notice on reorganising the price of non-residential natural gas, issued by the National Development and Reform Commission

the Price of Non-Residential Natural Gas on February 28, 2015, merging the prices of stored gas and incremental gas, as well as partially lifting the control over gate prices for commercial users. After adjustments, the maximum natural gas gate price for each province was as shown in Table 6.6.

\subsubsection{The Effect of Pricing Mechanisms in Keeping Natural Gas Prices Low}

Prior to June 2013, the National Development and Reform Commission set different prices for various uses of natural gas (see Table 6.7), but to a certain degree this pricing scheme conflicted with the natural gas use polices at the time. For example, gas use for chemicals was one of the areas prohibited by the policies, but in order to keep the price of fertilisers low, a relatively low price was set for natural gas used in fertilisers, which then acted as a signal that such usage was encouraged. Urban fuel gas use (non-industrial) was one of the natural gas use areas given priority by gas use policy, resulting in a lower price for supplies. However, even though the lower prices were beneficial for increasing market demand, it did not encourage greater supply. Due to there being a shortfall between supply and demand in the natural gas market, and for financial reasons, upstream enterprises prioritised supplies to higher priced users such as stable industrial users, who could support a higher price, which did not actually benefit the development of gas as an urban fuel.

Under strict government control, natural gas prices in China remained at a relatively low level for a long time. in 2012, the land-based natural gas price (excluding tax) for domestic manufacturers was $1.06 \mathrm{CNY} / \mathrm{m}^{3}\left(1.2 \mathrm{CNY} / \mathrm{m}^{3}\right.$ with tax added), which was equivalent to only a quarter of the WTI oil price at that time, a quarter of the CIF value of imported LPG, a third of the CIF value of imported fuel oil, half of the CIF value of imported Central-Asian natural gas, or a quarter of the CIF value of imported Qatar LNG. In 2012, the average price of residential gas in 36 major cities was $2.43 \mathrm{CNY} / \mathrm{m}^{3}$, while $\mathrm{LPG}$ was priced at $7.65 \mathrm{CNY} / \mathrm{kg}$ and residential electricity 
Table 6.7 Baseline manufacturer's prices (first-gate station) for domestic land-based natural gas after May 2010 price adjustments

\begin{tabular}{|c|c|c|}
\hline Name of oil/gas field & Type of user & $\begin{array}{l}\text { Manufacturer's baseline price } \\
\left(\mathrm{CNY} / 10^{3} \mathrm{~m}^{3}\right)\end{array}$ \\
\hline \multirow[t]{4}{*}{ Chuan-yu oil-gas field } & Fertilisers & 920 \\
\hline & $\begin{array}{l}\text { Direct supply to } \\
\text { industry }\end{array}$ & 1505 \\
\hline & Urban use (industrial) & 1550 \\
\hline & $\begin{array}{l}\text { Urban use } \\
\text { (non-industrial) }\end{array}$ & 1150 \\
\hline \multirow[t]{4}{*}{ Changqing oil field } & Fertilisers & 940 \\
\hline & $\begin{array}{l}\text { Direct supply to } \\
\text { industry }\end{array}$ & 1355 \\
\hline & Urban use (industrial) & 1400 \\
\hline & $\begin{array}{l}\text { Urban use } \\
\text { (non-industrial) }\end{array}$ & 1000 \\
\hline \multirow[t]{4}{*}{ Qinghai gas field } & Fertilisers & 890 \\
\hline & $\begin{array}{l}\text { Direct supply to } \\
\text { industry }\end{array}$ & 1290 \\
\hline & Urban use (industrial) & 1290 \\
\hline & $\begin{array}{l}\text { Urban use } \\
\text { (non-industrial) }\end{array}$ & 890 \\
\hline \multirow[t]{4}{*}{ Various oil fields in Xinjiang } & Fertilisers & 790 \\
\hline & $\begin{array}{l}\text { Direct supply to } \\
\text { industry }\end{array}$ & 1215 \\
\hline & Urban use (industrial) & 1190 \\
\hline & $\begin{array}{l}\text { Urban use } \\
\text { (non-industrial) }\end{array}$ & 790 \\
\hline \multirow[t]{4}{*}{ Various oil fields in Tibet } & Fertilisers & 790 \\
\hline & $\begin{array}{l}\text { Direct supply to } \\
\text { industry }\end{array}$ & 1215 \\
\hline & Urban use (industrial) & 1190 \\
\hline & $\begin{array}{l}\text { Urban use } \\
\text { (non-industrial) }\end{array}$ & 790 \\
\hline \multirow{4}{*}{$\begin{array}{l}\text { Various oil fields in Dagang, Niaohe, } \\
\text { Zhongyuan }\end{array}$} & Fertilisers & 940 \\
\hline & $\begin{array}{l}\text { Direct supply to } \\
\text { industry }\end{array}$ & 1570 \\
\hline & Urban use (industrial) & 1570 \\
\hline & $\begin{array}{l}\text { Urban use } \\
\text { (non-industrial) }\end{array}$ & 1170 \\
\hline \multirow[t]{4}{*}{ Other oil fields } & Fertilisers & 1210 \\
\hline & $\begin{array}{l}\text { Direct supply to } \\
\text { industry }\end{array}$ & 1610 \\
\hline & Urban use (industrial) & 1610 \\
\hline & $\begin{array}{l}\text { Urban use } \\
\text { (non-industrial) }\end{array}$ & 1210 \\
\hline
\end{tabular}


Table 6.7 (continued)

\begin{tabular}{|c|c|c|}
\hline Name of oil/gas field & Type of user & $\begin{array}{l}\text { Manufacturer's baseline price } \\
\left(\mathrm{CNY} / 10^{3} \mathrm{~m}^{3}\right)\end{array}$ \\
\hline \multirow[t]{4}{*}{ West-East Gas Pipeline } & Fertilisers & 790 \\
\hline & $\begin{array}{l}\text { Direct supply to } \\
\text { industry }\end{array}$ & 1190 \\
\hline & Urban use (industrial) & 1190 \\
\hline & $\begin{array}{l}\text { Urban use } \\
\text { (non-industrial) }\end{array}$ & 790 \\
\hline \multirow[t]{4}{*}{ Zhong-Wu Line } & Fertilisers & 1141 \\
\hline & $\begin{array}{l}\text { Direct supply to } \\
\text { industry }\end{array}$ & 1541 \\
\hline & Urban use (industrial) & 1541 \\
\hline & $\begin{array}{l}\text { Urban use } \\
\text { (non-industrial) }\end{array}$ & 1141 \\
\hline \multirow[t]{4}{*}{ Shaanxi Beijing Line } & Fertilisers & 1060 \\
\hline & $\begin{array}{l}\text { Direct supply to } \\
\text { industry }\end{array}$ & 1460 \\
\hline & Urban use (industrial) & 1460 \\
\hline & $\begin{array}{l}\text { Urban use } \\
\text { (non-industrial) }\end{array}$ & 1060 \\
\hline Sichuan going east pipeline & & 1510 \\
\hline
\end{tabular}

was priced at $0.53 \mathrm{CNY} / \mathrm{kWh}$. The calorific value of natural gas is $8000 \mathrm{kcal} / \mathrm{m}^{3}$, for LPG it is $12,000 \mathrm{kcal} / \mathrm{m}^{3}$ and for electricity it is $860 \mathrm{kcal} / \mathrm{kWh}$. In other words, for the same calorific value the price of natural gas was only $48 \%$ of the price of LPG, and $49 \%$ of the electricity price. Although a lower price for natural gas is beneficial in the short term for promoting gas use, it does not reflect the market value of clean and efficient energy sources, while also contributing to the conflicts between supply and demand, thus affecting both the supply of resources and sustainable healthy natural gas market development.

\subsubsection{The Influence of a High Fixed Price for Natural Gas}

In the 2013 natural gas price reform, the price restrictions on high-cost gas sources, such as LNG and unconventional natural gas, which make up a sixth of the entire market, were lifted, allowing the market to determine prices instead. However, price controls were kept in place for domestically produced and pipeline gases, which account for the remaining five-sixths of the market supply. Based on the 2013 natural gas price reforms, incremental gas was adjusted to $85 \%$ of the price of alternative energy in one move, and classifications according to usage were no longer applied. The price of stored gas was raised by $400 \mathrm{CNY} / 1000 \mathrm{~m}^{3}$, while the price of domestic gas was not adjusted (see Table 6.8). Against the backdrop of insufficient overall natural gas market supply, removal of pricing restrictions on high-cost gas sources and adjusting the pricing mechanism for natural gas by a reasonable amount should have encouraged supply and alleviated conflicts between supply and demand. However, this was not a successful move as far as encouraging natural gas consumption, and resulted in a lack of market demand for natural gas.

In the 2013 price adjustments, the volume of stored gas was 112.0 billion $\mathrm{m}^{3}$, but for 
Table 6.8 Gate natural gas prices by province after the 2013 price reform

\begin{tabular}{|l|l|l|l|l|l|}
\hline Province & Stored gas & Incremental gas & Province & Stored gas & Incremental gas \\
\hline Beijing & 2260 & 3140 & Hubei & 2220 & 3100 \\
\hline Tianjin & 2260 & 3140 & Hunan & 2220 & 3100 \\
\hline Hebei & 2240 & 3120 & Guangdong & 2740 & 3320 \\
\hline Shanxi & 2170 & 3050 & Guangxi & 2570 & 3150 \\
\hline Inner Mongolia & 1600 & 2480 & Hainan & 1920 & 2780 \\
\hline Liaoning & 2240 & 3120 & Chongqing & 1920 & 2780 \\
\hline Jilin & 2020 & 2900 & Sichuan & 1930 & 2790 \\
\hline Heilongjiang & 2020 & 2900 & Guizhou & 1970 & 2850 \\
\hline Shanghai & 2440 & 3320 & Yunnan & 1970 & 2850 \\
\hline Jiangsu & 2420 & 3300 & Shaanxi & 1600 & 2480 \\
\hline Zhejiang & 2430 & 3310 & Gansu & 1690 & 2570 \\
\hline Anhui & 2350 & 3230 & Ningxia & 1770 & 2650 \\
\hline Jiangxi & 2220 & 3100 & Qinghai & 1530 & 2410 \\
\hline Shandong & 2240 & 3120 & Xinjiang & 1410 & 2290 \\
\hline Henan & 2270 & 3150 & & & \\
\hline Unit & 3 & & & \\
\hline
\end{tabular}

Unit (CNY/thousand $\left.\mathrm{m}^{3}\right)$

Data source Pricing Notice (2013)1246 of the National Development and Reform Commission concerning adjustment of the natural gas price

incremental gas it was only 11.0 billion $\mathrm{m}^{3}$, accounting for 91 and $9 \%$ respectively. Although incremental gas only accounts for a small share, its price rose more, directly affecting the growth of market demand for natural gas. Taking the Beijing gate price of $3.14 \mathrm{CNY} / \mathrm{m}^{3}$, for example, for the same calorific value it would cost 3.5 times more than coal (calorific value of $5500 \mathrm{~kJ} / \mathrm{kg}, 620 \mathrm{CNY} / \mathrm{ton}), 0.87$ times the price of oil fuel (calorific value of $10,000 \mathrm{~kJ} / \mathrm{kg}$, $4520 \mathrm{CNY} /$ ton), and 0.70 times the price of LPG (calorific value of $12,000 \mathrm{~kJ} / \mathrm{kg}, 6700 \mathrm{CNY} /$ ton). Given the relatively high distribution costs, at this price natural gas is less competitive. In 2014, economic development in China entered the "new norm" era, and economic growth began to slow, while dropping coal prices and abundant hydroelectricity resulted in reduced demand for natural gas for power generation. The growth in natural gas consumption has been significantly lower than that predicted, with growth for last year of only $8.9 \%$, which was considerably lower than the average of $17.4 \%$ over the last 10 years.

\subsubsection{Removal of Natural Gas Price Restrictions Would See the Disappearance of Natural Gas Use Policies}

Government natural gas price regulation, whether it is set high or low, is detrimental to creating equilibrium between supply and demand in the market and encouraging sustainable development of the natural gas industry. The experiences of the United States and China in managing the natural gas industry reveal that government restrictions on natural gas prices tend to cause a serious imbalance of market supply and demand, resulting in the need for further direct government intervention. Moreover, experience in the United States also indicates that with the removal of price restrictions the market will actively reallocate resources, and this automatically increases social benefits and optimises the economic gains associated with natural gas to their maximum potential. The best method to ensure the environmental benefits of natural gas is to 
increase the cost of pollution abatement associated with highly polluting fuels.

Among the different uses of natural gas, household use has the highest tolerance towards rising prices, not being sensitive to changes in gas price. Based on statistics for 2012, the national household use of natural gas was only $17.85 \mathrm{~m}^{3} /$ month per household, while in Beijing households it was $18.5 \mathrm{~m}^{3} /$ month per household. Given the gate price of $3.14 \mathrm{CNY} / \mathrm{m}^{3}$, even after adding the distribution and peak regulation costs, the price of natural gas for household use would not exceed $5 \mathrm{CNY} / \mathrm{m}^{3}$. In terms of competition between natural gas and electricity, with the price for household electricity use being $0.54 \mathrm{CNY} / \mathrm{kWh}$, if the price of natural gas for household use exceeds $5 \mathrm{CNY} / \mathrm{m}^{3}$, household users will stop using natural gas. Even if calculated at $5 \mathrm{CNY} / \mathrm{m}^{3}$, the average natural gas cost for each Beijing household is only CNY 90/month. As the average annual disposable income for Beijing citizens was CNY 40,321 in 2013, natural gas consumption accounted for less than $1 \%$ of household income.

When compared to coal, natural gas has advantages as an industrial fuel. For example, it has a better calorific value, is capable of raising temperatures more quickly, is clean and non-polluting, and it can be easily switched on and off. It is also effective in tackling problems such as sulphur dioxide and phenol emissions, tarring and particulate pollution, thus improving quality and economic effectiveness in industries such as pottery, glass and non-ferrous metals, which also increases its competitiveness. When considered from the point of view of China's overall energy needs, China has only limited natural gas supplies, therefore natural gas could never completely replace coal. From the point of view of the atmosphere as a whole, "coal conversion to gas" does not completely overcome this problem, the more important issue being to increase clean coal use. The main uses for natural gas in the chemical industry are the production of ammonia and methanol, and these are the most sensitive to price changes in natural gas. Regardless of whether ammonia or methanol production is concerned, coal is a serious competitor with natural gas for use as raw material in the chemicals industry. At the same time as the ratio of coal use in energy source structure is being reduced, coal prices are falling, thus offering greater advantages to the coal chemicals industry than to the gas chemicals industry. If natural gas pricing mechanisms were liberalised, this would result in a decline in natural gas's share of use in the chemicals industry, without the need for government intervention.

\subsection{The Relevance of the 1978 U.S. Natural Gas Policy Act for China}

In 1978, during the international oil crisis, in the face of panic caused by lowering domestic production and natural gas reserves on the brink of exhaustion, the United States Congress passed the Fuel Use Act (FUA), restricting oil and natural gas in power generation and for industrial purposes. The legislative background and the contents of the Fuel Use Act are similar to some extent to the "Natural Gas Use Policy" adopted by the National Development and Reform Commission. The way in which the FUA affected development of the natural gas industry in the United States provides a valuable reference for policies affecting China's natural gas industry.

\subsubsection{Legislative Background}

In order to protect the interests of independent producers and the end user, and prevent natural gas manufacturers and pipeline operators from colluding in monopolistic profiteering, in 1954 the Supreme Court of the United States gave its decision against Phillips Petroleum Co., authorising the Federal Power Commission (FPC) to regulate interstate natural gas wellhead prices. The FPC stipulated that wellhead prices must be determined "based on historical costs", regardless of stored amount, alternative energy source prices or changes in consumption. The main effect of this was to protect the short-term 
interests of consumers. However, it interfered with the investment necessary for manufacturers to increase future supply. In 1973, the production of natural gas in the United States reached a peak, at an annual volume of 615.4 billion $\mathrm{m}^{3}$, and then began to fall. In 1978 production was at 555.8 billion $\mathrm{m}^{3}$, and in 1986 it was as low as 454.7 billion $\mathrm{m}^{3}$, dropping by a quarter from peak levels (see Fig. 6.1).

In October 1973 the first oil crisis broke out, causing massive oil price inflation, and yet the natural gas wellhead prices remained under regulation, worsening the natural gas supply situation. The price regulation caused an increase in demand and insufficient supply, and when combined with the effects of the oil crisis, this led to natural gas supply shortages in the United States in the 1970s. Between 1976 and the winter of 1977 , at the worst point of the natural gas shortage, more than 9000 factories were forced to suspend production, 750,000 people lost their jobs and hundreds of schools in the Midwest and Northeast had to be closed, causing several billion dollars of losses to the US manufacturing industry. That period in the development of the
US natural gas industry is now referred to as the "era of failure".

The catalyst for the Fuel Use Act was the peak gas theory, which predicts that natural gas will eventually be depleted after peak production is reached. In 1976, Exxon Oil published a report said to be the result of research conducted by over a hundred top geologists and geophysicists. The report stated that the total remaining natural gas resources in the United States were only $287 \times 10^{12} \mathrm{cf}$ (around $8 \times 10^{12} \mathrm{~m}^{3}$ ). In fact, from 1976 to 2012, the actual natural gas production in the United States was close to $20 \times 10^{12} \mathrm{~m}^{3}$, and at the end of 2012 there were still discovered resources of $8.5 \times 10^{12} \mathrm{~m}^{3}$.

\subsubsection{Contents of the Legislation}

Since the natural gas wellhead price restrictions only applied to interstate natural gas trade, pipeline companies buying natural gas within a state were not affected by the FPC price controls. As a result, there were no supply shortages in the major natural gas exporting states. When winter

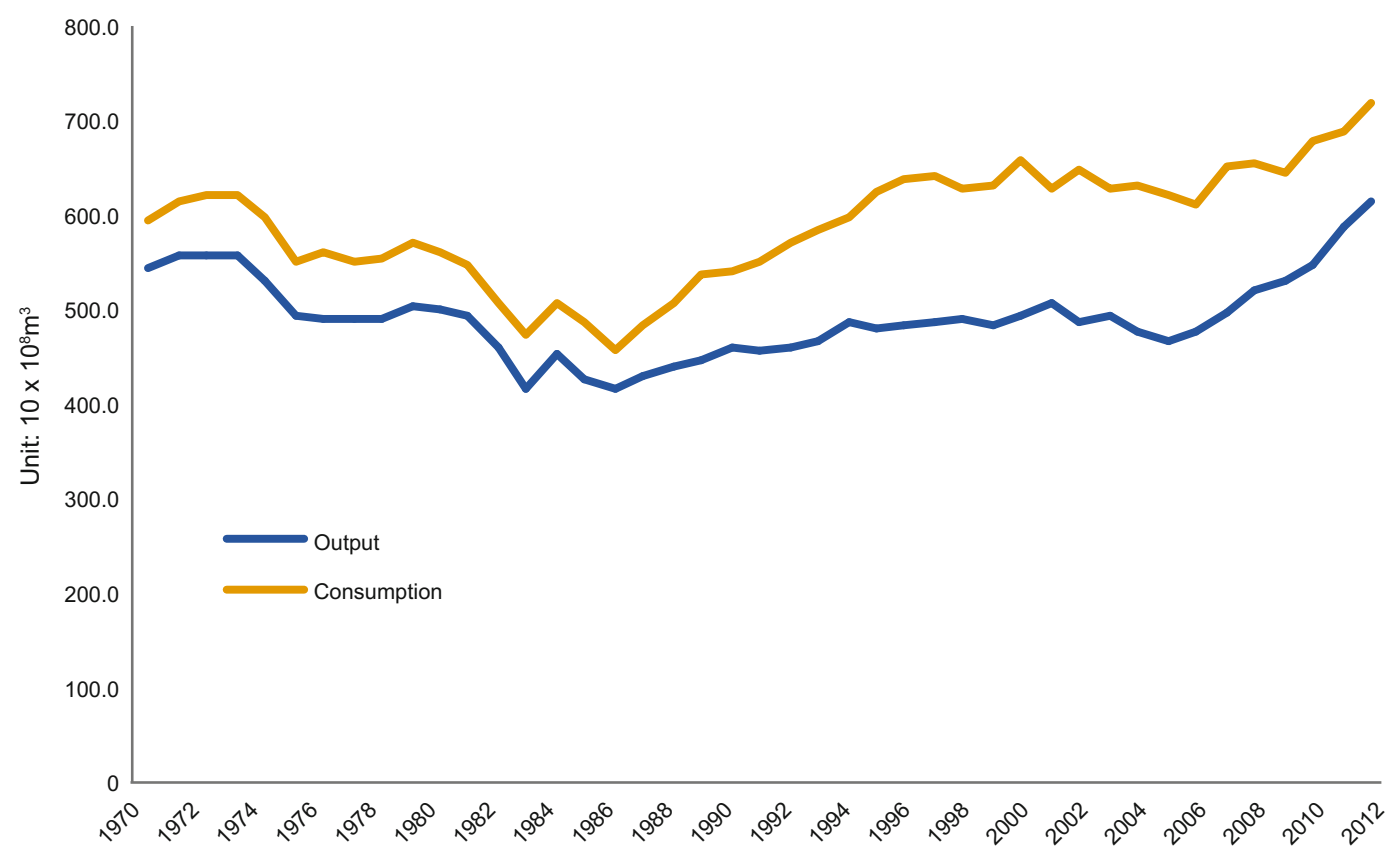

Fig. 6.1 Changes in production and consumption of natural gas in the United States from 1970 to 2012 
approached, while the northern schools and commercial establishments had to close because of the lack of natural gas supplies, Texas was still using natural gas as a replacement for oil and coal in power generation, rather than shipping it up north. There were suggestions that the price restrictions should be lifted to let natural gas be traded at market prices. However, the public utilities representatives of both the major parties decided to trust the "experts" and their theory of resource depletion. They believed that the signs of depletion were already recognisable, and they felt that deregulation of natural gas prices was a selfish, short-sighted and idiotic solution. In their opinion it was necessary to continue with resource protection subsidies, terminal usage controls and pricing control, which would raise efficiency and ensure fairness all round.

In May 1978, the United States Congress passed two acts: the Power Plant and Industrial Fuel Use Act (FUA) and the Natural Gas Policy Act (NGPA). The NGPA was mainly a redesign of the regulatory regime and categorisation of natural gas well types, raising the price of natural gas from "old wells", and partially removing price restrictions on "new wells". The FUA is a supplementary act to the NGPA, authorising the Department of Energy (DOE) to issue orders restricting the use of natural gas to specific industries, in an attempt to directly control the use of natural gas. Apart from forbidding the building of new natural gas power plants and industrial boilers, the FUA further demanded that factories should abandon fuel switching capabilities, while encouraging factories using natural gas to switch to using other fuels. After 1990, the use of natural gas was banned in power plants and industrial boilers. In the transitional period, use of natural gas in public works was restricted to consumption volumes equivalent to those encountered during the energy crisis from 1974 to 1976.

\subsubsection{Implementation}

In the process of setting out the FUA, the United States Congress firmly believed that natural gas resources were in the process of being depleted, and could not possibly have predicted that an excess of natural gas would arise. Yet, while the ink was still wet on the FUA, Secretary of Energy James Schlesinger announced that there were predicted natural gas reserves in excess of the $1 \times 10^{12} \mathrm{ft}^{3}$. He did state, however, that this "bubble" was only temporary. While the "bubble" lasted, the Department of Energy supported a delay in switching to coal as demanded by the FUA, and encouraged industrial fuel users capable of switching energy sources to use "surplus" natural gas instead of oil.

The loosening of restrictions on wellhead prices increased the supply of natural gas, with high fixed prices limiting demand, and "take-or-pay" contracts locking up a large volume of higher-priced natural gas, which caused a "bubble" to occur in the natural gas market, with supply exceeding demand. As this bubble economy persisted, the FUA's restrictions on natural gas use became a historically significant mistake and resulted in the market imbalance worsening. In 1981, Congress overruled the FUA's power plant requirements and then in 1987 Congress repealed the FUA and withdrew all the regulations responsible for restricting natural gas consumption.

\subsubsection{Lessons for Natural Gas Usage Policy in China}

The Natural Gas Use Policy, as adopted by the National Development and Reform Commission, is not only similar in content to the 1978 Fuel Use Act of the United States, they also share a similar background, market environment and policy climate.

- The natural gas market in China has been growing rapidly since 2000; demand for natural gas has been rising, but the growth in domestic production remains slow, leading to increasing reliance on imported natural gas. This is similar to the uncertainties regarding future energy source supplies in the United States during the 1970s. 
- The United States had yet to carry out natural gas industry reforms in the 1970s, and pipeline transportation and sales of natural gas were bundled together. The situation in which natural gas wellhead price restrictions were put into place was therefore similar to that when the Natural Gas Use Policy was enacted in China.

- Natural gas prices in China have been frequently adjusted since 2000, and from 2013 onwards natural gas prices were pegged to oil prices and LPG prices. Lifting regulation of unconventional natural gas and imported LNG prices would have the same effect as when the United States removed "new wells" pricing regulation in the FUA of 1978.

- Due to the higher value of natural gas, there has been a great deal of activity in development of unconventional natural gas in China, while a large number of natural gas import contracts have been signed with offshore partners. This is also reminiscent of how, after "new well" price regulation was lifted in the United States in 1978, there was extensive development of extraction of the more expensive "deep-level gas".

- After suffering more than a decade of shortages, United States pipeline companies eagerly signed long-term "take-or-pay" contracts with gas suppliers at high prices, in order to ensure capacity to satisfy the demands of users lower down on the supply chain, thus creating the conditions necessary for the "bubble" to occur. Contracts in the natural gas market in China are also in the form of "take-or-pay", and when supplies come under pressure, local governments opt for a "give me gas, disregard the price" approach out of fear.

- Due to the effects of the long-term shortage in the United States, in 1980, industrial and public power generation natural gas consumption was $20 \%$ lower than in the 1970 s, with many industries having learned how to switch fuels and save energy; nearly all new power plants were coal- or nuclear-powered. As gas prices continue to rise, it will become difficult to continue using natural gas in power generation in China, and enthusiasm for natural gas in industrial uses will fall, with coal-fired power stations preferring to adopt a clean coal use approach rather switching to gas.

In a 2013 forecast, the gap between natural gas supply and demand in China would be as big as 22.0 billion $\mathrm{m}^{3}$. In fact, due to the National Development and Reform Commission's largescale adjustment of pipeline gas prices in June, stored gas price went up by $400 \mathrm{CNY} / 10^{3} \mathrm{~m}^{3}$, while the incremental gas price is now pegged against alternative energy sources, pushing it upwards to $1380 \mathrm{CNY} / 10^{3} \mathrm{~m}^{3}$. This has resulted in many gas power stations adjusting their power generation plans and has resulted in a decline in industrial gas use. In addition, with relatively warm winters, China National Petroleum Corporation was actually able to put gas into storage during the winter, all of which are signs of an excess in supply. What we can learn from the FUA in the United States is that it is necessary to make timely adjustments, and to repeal natural gas use regulations when it becomes necessary.

\subsection{Policy Recommendations for Encouraging Natural Gas Use}

The pressures of environmental protection and emission reduction mean that China needs to be more active in developing natural gas and encouraging its use. The nature of current natural gas use policies in China is such that, when demand exceeds supply and pricing mechanisms are no longer effective, the government interferes with supply and demand directly, mainly by applying restrictions to gas use in specific sectors. In the past decade, with the widespread development of natural gas sources, China has reached a stage where a range of locally produced gas, gas synthesised from coal, imported pipeline gas and imported LNG is available, greatly boosting the available quantity and stability of natural gas supplies. The "shale natural gas revolution" in the United States teaches us 
that as technology for natural gas extraction develops, the extent of natural gas reserves available for extraction will increase. As natural gas prices in China are adjusted to more acceptable levels, the scale of supply has increased, and there has been a reversal in the previous supply-demand scenario, currently manifesting as a lack of demand. China must therefore alter its current policy of restricting natural gas use, and instead promote and encourage a wider range of uses for natural gas.

\subsubsection{Improve Environmental Supervision, Replacing Dispersed Coal Use with Natural Gas}

The energy supply in China is said to be "coal-heavy, oil-deprived and short of gas". Even though various sources of natural gas have been introduced in the last decade, vastly enhancing the natural gas supply capacity, in the face of the tremendous demand for energy in China, the supply of natural gas available to China is still limited. Natural gas is not likely to completely replace coal, although it could be prioritised to replace dispersed coal use. In OECD countries, the ratio of coal used for power generation is $78 \%$, while $90 \%$ of coal consumed in the United States is for power generation. Dispersed coal use is relatively concentrated in the steel and concrete industries, but very dispersed coal use is rare. In terms of total coal consumption in China, only half of it is used for power generation, the other half being used in dispersed coal burning. Of dispersed coal burning uses, half is used in metal smelting and cement sintering and other relatively concentrated uses, for which coal is essential, the other half being used in heating, textiles, paper manufacturing and other very dispersed fields. When coal use is too dispersed, energy efficiency is low and large volumes of pollutants result, resulting in increased pollution control costs. Natural gas substitution would therefore apply mainly to the replacement of very dispersed coal use.
Since coal is relatively cheap, natural gas does not have a competitive advantage in terms of price, therefore businesses prefer coal based purely on economic considerations. Encouragement of the replacement of coal by natural gas mainly comes from environmental protection policies.

- More rigid emission standards should be stipulated and, whether for concentrated or dispersed coal uses, all users should stay within emissions targets. By internalising what was originally an external cost of using coal, the competitiveness of natural gas would improve.

- A new supervisory structure should be devised, so that concentrated coal use can be supervised in real time and online, in order to prevent companies from installing but not using emission reduction and pollution control facilities, or only using them from time to time.

- In areas subject to urban planning or areas affected by acid rain, coal burning should be restricted or prohibited.

- Where gas supplies allow, in facilities where the cost of restricting emissions is too high or where it would be impractical to introduce emissions restrictions, conversion to gas could be obligatory. For those in regions where conditions do not allow for gas supplies, construction of new installations which require dispersed coal use which are not absolutely necessary in terms of everyday life should not be permitted. At the same time, more efforts should be put into building gas infrastructure, so that more regions could opt to use natural gas.

\subsubsection{Optimise the Electricity Pricing Scheme, and Increase the Economical Natural Gas Power Generation}

The key to increasing the ratio of natural gas in total energy source consumption structures is the 
development of natural gas power generation. Natural gas power generation is clean, occupies less space and provides effective peak regulation. It is well suited for provision of supplementary power to large cities or megacities. In developed countries, natural gas power generation usually takes up around $40-60 \%$ of total natural gas consumption. In China, on the other hand, only $15 \%$ of total natural gas used is for power generation. While there is much space for development, the biggest hurdle for expansion of natural gas power generation is the relatively high cost of natural gas power compared to coal power. Based on calculations, the cost of coal power generation is only $0.34 \mathrm{CNY} / \mathrm{kWh}$, whereas natural gas power generation costs as much as $0.65 \mathrm{CNY} / \mathrm{kWh}$ (annual power generation of $35,000 \mathrm{~h}$ ), or $0.615 \mathrm{CNY} / \mathrm{kWh}$ (annual power generation of $5000 \mathrm{~h}$ ). Under the current subsidy regime, natural gas-generated power is more expensive and there is no incentive for power grid companies to buy natural gas-generated power. With a high natural gas price, there is nothing to be gained from natural gas power generation, and power generating companies have shown little interest in it.

There are two ways to promote natural gas power generation, both of which aim to improve the economic benefits of natural gas power generation. The first method involves introducing local production of core technology, especially the manufacturing of gas turbines, so that unit investment costs and long-term maintenance and inspection costs can be lowered. The second method is to increase power generation operational cycles, lowering the fixed cost of each $\mathrm{kWh}$ of electricity produced. However, the amount of leeway gained in terms of lowering costs is very limited. Based on calculations, using locally manufactured core technology would only bring the cost of power generation down by $0.024 \mathrm{CNY} / \mathrm{kWh}$. Increasing the length of the power generation operational cycles would move natural gas power generation towards playing a base-loading role, lessening the gains it can achieve as a supplementary power source in peak generation. Currently there are no auxiliary service markets or peak/trough electricity pricing mechanisms in China. The main policy adopted has been subsidising natural gas power generation by setting a higher electricity price. In large cities such as Shanghai, Beijing and Shenzhen, a two-part tariff is charged for electricity, the capacity price being $40-46 \mathrm{CNY} / \mathrm{kW}$ month, basically covering the fixed costs of natural gas power generation. On top of the two-part tariff, auxiliary service markets should also be developed, switching from government regulation of prices to market-regulated prices to provide such subsidies.

\subsubsection{Strengthen Planned Guidance to Promote Natural Gas in Transportation}

For transportation, the gases used are mainly CNG and LNG, which replaces petrol, diesel and ship fuel. Based on data provided by the Environmental Protection Department, around a quarter of all atmospheric pollution in China comes from exhaust gases. When natural gas is used as a replacement transportation fuel, vehicles emit less carbon dioxide compared to oil-burning vehicles, and they hardly emit any other pollutants such as nitrogen oxide and sulphides. Furthermore, the relatively large gap between natural gas and oil prices, and the absence of goods and services tax, means that natural gas vehicles are more economical than oil-burning vehicles. For example, in the case of a taxi that runs on $\mathrm{CNG}$, there was a period of time when the price of $\mathrm{CNG}$ was half that of petrol, and hence the investment of several thousand $\mathrm{CNY}$ required for conversion could be recovered in a matter of months. Backed by atmospheric pollution control measures and its economical characteristics, use of natural gas in transportation in China has been growing quickly, from 97,000 vehicles in 2005 to 2.3 million natural gas-powered vehicles in 2014; the associated annual gas consumption reached 22.5 billion $\mathrm{m}^{3}$, making up $12.3 \%$ of total natural gas consumption. LNG filling stations increased from 241 stations in 2011 to 2000 stations in 2014. 
As natural gas transportation technology matures, it brings more economic benefits, but there are specific hindrances to the development of natural gas use in the transportation sector. Unlike household, industrial, power generation or other uses where the users stay in a fixed location, natural gas used in transportation is supplied to moving users and relies heavily on supply networks. Natural gas fuel, filling stations and transportation form the core of the natural gas transport use value chain, each segment affecting the decision of a user on whether to choose natural gas over all other alternatives; this in turn may slow down or hamper the development of natural gas use in the transportation sector. As the natural gas supply situation in China improves, the supply of natural gas fuel is assured for the foreseeable future. However, the government still needs to strengthen planning and guidance and refine related policies and standards, in order to increase the provision of infrastructure such as natural gas filling stations and standardised filling services, thus ensuring that the natural gas filling station network better fulfils the mobile needs of transportation and logistics users, thereby attracting users to adopt natural gas, accelerating growth in the natural gas transport sector.

\subsubsection{Reduce Cross-Subsidisation Between Different Users, and Encourage Industrial and Commercial Natural Gas Use}

In China, urban natural gas use is considered to be one of the benefits of city life. Since residential gas is associated with very low profit margins, with supplies sometimes being provided at a loss, the financial shortfall due to cheap household natural gas is made up by charging a higher natural gas price to the industrial and commercial sectors. For example, after the upstream natural gas prices were adjusted in 2013, the Beijing gate price for stored gas was
$2.26 \mathrm{CNY} / \mathrm{m}^{3}$ and for incremental gas was $3.14 \mathrm{CNY} / \mathrm{m}^{3}$, but government pricing departments set the price of residential use gas at $2.28 \mathrm{CNY} / \mathrm{m}^{3}$. It is clear that sales to household users were made at a loss, compensated for by industrial and commercial use. The subsidisation of household natural gas use by the industrial and commercial sectors is in fact passed on to society in its use of products and services. The higher household income is, the more hot water and heating a household uses, and the more it benefits from the natural gas subsidies. In contrast, households with lower incomes, or households that are not natural gas users or that only use a small amount of natural gas, would not benefit from, or only benefit slightly from, these subsidies. That households with higher incomes should benefit more from such subsidies cannot be seen as fulfilling the original objectives of government policy and is hardly fair.

Not only is an all-encompassing subsidy for household natural gas use unfair, it is also unsustainable and unnecessary. On the one hand, there is much room for growth in household natural gas use, and with volumes expected to increase from the 2012 figure of 28.8 billion $\mathrm{m}^{3}$ to 54.8 billion $\mathrm{m}^{3}$ by 2020 , the continuance of such subsidies would be enormously difficult. On the other hand, household natural gas use is less price-sensitive, and hence there is no real need for subsidies. From the point of view of economic competitiveness, as long as the price is lower than $4 \mathrm{CNY} / \mathrm{m}^{3}$, natural gas will still be competitive against oil fuel, LPG and electricity. City dwellers use an average of around $60 \mathrm{~m}^{3}$, and even if the price of each cubic metre goes up by CNY 1, the annual increase is still only CNY 60. In 2013, low-income urban households (the lowest 20\%) had a disposable income of CNY 11,434 , and an increase in natural gas expenditure of CNY 60 is equivalent to only 5\% of disposable income. Therefore, the price of natural gas for household users could definitely be set above the cost of supplying the gas, cancelling the cross-subsidising between household use and industrial and commercial use, reducing the cost 
of using natural gas to the industrial and commercial sectors, and thus encouraging the growth of industrial and commercial natural gas use. As for the specifics of the price adjustments, local governments should decide the timing and magnitude of them.

\subsubsection{Extend Carbon Emission Trading Rights, and Actualise the Environmental Value of Natural Gas}

The key to encouraging the use of natural gas in power generation as well as in the industrial and commercial sectors is to improve the competitiveness of natural gas against coal. If considering the price alone, natural gas cannot compete against coal, as the fuel cost per $\mathrm{kWh}$ of coal power generation is a mere CNY 0.21 , while that of natural gas is CNY 0.50. As a clean energy source, natural gas has an environmental value, and when competing against coal this environmental value could be considered as the external environmental cost of coal. The external cost of coal burning could be broken down into specific pollutant emissions costs, such as dust, nitrogen oxides and sulphur dioxide, in addition to a carbon emissions cost. With increased investment, the pollutants released by coal burning can be lowered to a level close to that encountered where gas is used as the fuel. Newly constructed coal-burning power stations can basically achieve the same level of atmospheric pollutant emissions as natural gas power stations (when baseline oxygen content is $6 \%$, dust, sulphur dioxide, nitrogen oxides concentrations are respectively above 10,35 and $50 \mathrm{mg} / \mathrm{m}^{3}$ ), while the increase in investment cost for each $\mathrm{kWh}$ is only CNY $0.01-0.02$. Therefore, simply strengthening enforcement of environmental regulations and restricting release of air pollutants would not effectively increase the competitiveness of natural gas against coal in the power generation sector.

Another method for boosting the competitiveness of natural gas is the levying of a carbon tax, but while a carbon tax can narrow the gap between the costs of coal power generation and natural gas power generation, thereby making natural gas comparatively more competitive, it would nonetheless increase the absolute cost of both forms of power generation. A better way of making natural gas more competitive is to set a carbon allowance for each $\mathrm{kWh}$, and fully utilise trading of carbon emission rights. For example, if coal power generation has a carbon emission of $0.8 \mathrm{~kg} / \mathrm{kWh}$ while gas power generation's carbon emission is $0.37 \mathrm{~kg} / \mathrm{kWh}$ and the government sets the carbon allowance at $0.7 \mathrm{~kg} / \mathrm{kWh}$, then coal power stations have to purchase $0.1 \mathrm{~kg} / \mathrm{kWh}$ of emission rights from the market, while natural gas power stations have $0.33 \mathrm{~kg} / \mathrm{kWh}$ of emission rights for sale. If there are only coal and natural gas power generation to choose from, then the electricity generated by coal cannot exceed 3.3 times the amount generated by natural gas; in other words, the proportion of the quantity of natural gas power generation would be $23 \%$ of total power generated, otherwise there would be insufficient emissions rights available for purchase by coal power stations. This would allow the government greater flexibility to adjust the natural gas power generation ratio, getting gas power generators to directly subsidise natural gas power generation, and forcing coal power generation to provide a direct subsidy to gas power generation, thereby taking full advantage of the environmental value of natural gas. 
Open Access This chapter is licensed under the terms of the Creative Commons Attribution 4.0 International License (http://creativecommons.org/licenses/by/4.0/), which permits use, sharing, adaptation, distribution and reproduction in any medium or format, as long as you give appropriate credit to the original author(s) and the source, provide a link to the Creative Commons license and indicate if changes were made.
The images or other third party material in this chapter are included in the chapter's Creative Commons license, unless indicated otherwise in a credit line to the material. If material is not included in the chapter's Creative Commons license and your intended use is not permitted by statutory regulation or exceeds the permitted use, you will need to obtain permission directly from the copyright holder. 